REGARDS

SUR L'ECONOMIE ALLEMAND

BULLETIN ECONOMIQUE DUCIRAC
Regards sur l'économie allemande

Bulletin économique du CIRAC

$67 \mid 2004$

Varia

\title{
Élargissement : l'économie des « Dix » déjà intégrée
}

Isabelle Bourgeois

\section{CpenEdition}

Journals

Édition électronique

URL : http://journals.openedition.org/rea/3807

DOI : $10.4000 /$ rea.3807

ISBN : 978-2-8218-0830-0

ISSN : 1965-0787

Éditeur

CIRAC

Édition imprimée

Date de publication : 1 juillet 2004

Pagination : 33

ISSN : 1156-8992

Référence électronique

Isabelle Bourgeois, "Élargissement : l'économie des « Dix » déjà intégrée », Regards sur l'économie allemande [En ligne], 67 | juillet 2004, mis en ligne le 08 octobre 2009, consulté le 15 septembre 2020 URL : http://journals.openedition.org/rea/3807

Ce document a été généré automatiquement le 15 septembre 2020

(C) CIRAC 


\title{
Élargissement : l'économie des « Dix » déjà intégrée
}

\author{
Isabelle Bourgeois
}

Les échanges de l'Allemagne avec les dix nouveaux Etats membres se sont intensifiés bien avant l'élargissement de l'UE le $1^{\mathrm{er}}$ mai dernier. Depuis 1993, les importations ont augmenté de plus de $16 \%$ par an en moyenne, les exportations croissant de près de $15 \%$. Dans la structure régionale des échanges, les « Dix » représentent aujourd'hui $9 \%$ de l'import et $11 \%$ de l'export allemand. La branche automobile illustre parfaitement la nature de ces liens : les acteurs allemands (comme les autres européens) ont localisé à l'est sites de production et d'assemblage, mettant à profit les salaires inférieurs d'une main d'œuvre qualifiée, mais aussi pour s'implanter au plus près d'un marché caractérisé par une forte demande de rattrapage. Et ces pays partenaires approvisionnent en retour le marché allemand (et européen) en véhicules ou pièces automobiles. L'intégration des marchés s'intensifiera avec la forte croissance attendue de l'économie des « Dix ». (IB)

Echanges de l'Allemagne avec les nouveaux Etats membres (en \%)

\begin{tabular}{|l|l|l|l|l|}
\hline & \multicolumn{2}{|l|}{ Export } & \multicolumn{2}{l|}{ Import } \\
\hline & Part en 2003 & $\begin{array}{l}\text { Evol. 1993-2003 } \\
\text { moyenne annuelle }\end{array}$ & Part en 2003 & $\begin{array}{l}\text { Evol. 1993-2003 } \\
\text { moyenne annuelle }\end{array}$ \\
\hline Pologne & 2,48 & 13,1 & 2,97 & 13,9 \\
\hline Rép. tchèque & 2,53 & 15,9 & 3,29 & 18,5 \\
\hline Hongrie & 1,79 & 16,8 & 2,30 & 18,7 \\
\hline Slovaquie & 0,78 & 32,2 & 138 & 26,5 \\
\hline Slovénie & 0,37 & 5,7 & 0,46 & 4,9 \\
\hline
\end{tabular}




\begin{tabular}{|l|l|l|l|l|}
\hline Lituanie & 0,24 & 22,4 & 0,14 & 16,9 \\
\hline Lettonie & 0,13 & 19,0 & 0,08 & 13,2 \\
\hline Estonie & 0,11 & 25,1 & 0,09 & 22,1 \\
\hline Chypre & 0,07 & $-0,2$ & 0,02 & 18,5 \\
\hline Malte & 0,04 & 0,7 & 0,05 & 4,7 \\
\hline Total des « $10 »$ & 8,55 & 14,7 & 10,77 & 16,2 \\
\hline UE 15 & 55,50 & 7,0 & 50,43 & 5,3 \\
\hline Total & 100 & 7,6 & 100 & 6,5 \\
\hline
\end{tabular}

Source des données : Destatis/HWWA, HWWA Wirtschaftsdienst 5/2004

\section{AUTEUR}

\section{ISABELLE BOURGEOIS}

élargissement, UE, Europe, Union européenne, commerce, commerce extérieur, relations économiques extérieures, politique étrangère 